\title{
Virtual water: an effective mechanism for integrated water resources management
}

\author{
Alaa El-Sadek \\ Associate Professor, College of Postgraduate Studies, Arabian Gulf University, Manama, Kingdom of Bahrain; \\ Corresponding Author: alaasa@agu.edu.bh, alaa elsadek@yahoo.com
}

Received 4 January 2011; revised 21 March 2011; accepted 7 June 2011.

\begin{abstract}
In regions, which suffer from water shortage or potential water shortage like the Middle East, water policies and different mitigation measures are formulated. With the increasing population and increasing demand for food and drinking water with the fixed supply of water, the demand management policies have been introduced. Virtual Water has been adopted as an alternative or potential alternative water resource. In the application of the Integrated Water Resources Management (IWRM), virtual water has to be considered as a resource of water. In this paper, the practical value of the virtual water concept as well as the possibility of the application of the concept in the regional and national level are discussed. The paper emphasizes on the application of virtual water in agriculture products and virtual water trade of these products. This research concluded that, there is a possibility for the application of the virtual water concept on the national level taking into account water endowments, and other natural and social economic conditions. The virtual water strategy seeks ways to consciously and efficiently utilize the internal and external water resources to alleviate water scarcity. This, however, by no means implies that importing food is the only response the water scarce countries and regions should and can take. Other measures concerning the supply and demand sides of water management are imperative. The argument here is that the virtual water strategy should be an integral component in the whole package of integrated water resources management.
\end{abstract}

Keywords: Virtual Water; IWRM; Global; Regional; Local; Strategy; Policy Option

\section{INTRODUCTION}

The uneven spatial distribution of water resources in the global level has created regions where water is scarce and regions where water is abundant. With regard to water demand, there are regions of low demand and others of high demand [1]. Unfortunately, there is no positive relation between supply and demand. Virtual water is economically invisible and politically silent [2]. This had made it possible in the past for water scarce countries to cope with the water deficit by importing food without cultivating a policy discourse of national water scarcity. Since the term virtual water explicitly came to the light in the mid 1990s, it has drawn a growing attention among policy makers, scientific communities, and the general public. In regions, which suffer from water shortage or potential water shortage like the Middle East, water policies and different mitigation measures are formulated [3].

Hoekstra [4] stated that there are three levels for decisions and improvements that can be taken. The first level is the user level where increasing user's awareness, applying water pricing and water saving technology would lead to improve in local water use efficiency. The second is the river basin level. In this level, evaluation of the value of water for different alternative uses has to be done in order to reallocate water in an economically efficient way and hence improve water allocation efficiency. The third level is the global level. The application of virtual water trade between water scarce and water abundant regions can achieve improvements in the global water use efficiency [5]. Many advances and improvements have been achieved in the first level, but in the second level although the concept is highly adopted but there is a great gap between the adoption of the concept and its application. The situation is even worse in the third level. The following paragraphs review and discuss the concept and application of virtual water as an instrument for improving global water use efficiency. 
Virtual water is defined as water 'embodied'in a product, not in real sense, but in virtual sense. It refers to the water needed for the production of the product [4]. The term virtual refers to the fact that at the end water that was used to produce the product is not contained in the final product. Virtual water has also been called 'embedded water' or 'exogenous water', the latter referring to the fact that import of virtual water into a country means using water that is exogenous to the importing country. Exogenous water is thus to be added to a country's 'indigenous water' [6]. If it comes to a more precise quantitative definition, principally two different approaches have been proposed and applied so far. In one approach, the virtual water content is defined as the volume of water that was in reality used to produce the product. This will depend on the production conditions, including place and time of production and water use efficiency. Producing one kilogram of grain in an arid country for instance can require two or three times more water than producing the same amount in a humid country. In the second approach, one takes a user rather than a producer perspective, and defines the virtual water content of a product as the amount of water that would have been required to produce the product at the place where the product is needed. This definition is particularly relevant if one poses the question: how much water do we save if we import a product instead of producing it ourselves? One main concept which is closely related to 'virtual water' is the 'water footprint'. 'Water footprint' of an individual, business or nation is defined as the total volume of fresh water that is used to produce the foods and services consumed by the individual, business or nation. A water footprint is generally expressed in terms of the volume of water use per year [4]. The value of virtual water as an alternative water resource is very crucial basically for water scarce countries.

Nowadays the Arab region is facing serious challenges arising from the implications of economic development. Perhaps one of the most critical challenges is the drastically decreasing per capita water availability in most of the Arab states. Policy development in the region failed to keep up with the accelerated changes in its socioeconomic context. This paper concerned with investigating the feasibility of one "policy option" that has often stirred conflicting opinions and sometimes accused of leading to insecurity. The concept of 'virtual water' has been introduced by Tony Allan in the early nineties $[7,8]$. It took nearly a decade to get global recognition of the importance of the concept for achieving regional and global water security. The first international meeting on the subject was held in December 2002 in Delft, the
Netherlands. A special session was devoted to the issue of virtual water trade at both the Third and Fourth World Water Forums [4]. The concern is with the possibility of using the concept as a planning tool and to present issues that need to be tackled before considering virtual water trade as a policy option. The "virtual water" content of a product, as often defined, is the volume of water used to produce the product, measured at the place where the product was actually produced (production site specific definition). The virtual water content of a product can also be defined as the volume of water that would have been required to produce the product in the place where the product is consumed (consumption site specific definition) [9].

\section{VIRTUAL WATER TRADE AS A POLICY OPTION}

It is often noted that net import of virtual water in a water-scarce nation can relieve the pressure on a nation's own water resources, and that Virtual water can be seen as an alternative source of water [4]. It is of no doubt that using this additional source can be an instrument in planning and managing water resources. Thus virtual water trade is an existing fact and it won't be feasible to argue whether or not countries should trade virtual water in the form of food products. This is what referred to as "conscious choice" in virtual water trade [10]. The argument is often entirely focused on optimizing the ongoing trade for the benefit of the trading states. This is where skepticism comes; which countries should benefit from virtual water trade? Can water poor nations benefit from the element of choice (i.e. can they choose what and who to trade with)? As long as trade is at stake, how can developing countries benefit from virtual water trade when their trade infrastructure is not up to the required standards?

Virtual water trade between or within nations can be seen as an alternative to real, inter-basin water transfers. Renault [11] notes that the issue of optimal production is not only a matter of wisely choosing the locations of production, but also a matter of proper timing of production. One can try to overcome periods of water shortage by creating artificial water reservoirs, but - as an alternative - one can also store water in its virtual form, e.g. by food storage. This can be a more efficient and more environmentally friendly way of bridging dry periods than building large dams for temporary water storage. The strength of the virtual water concept is that it embraces the whole water management in a country or basin and allows for a deeper understanding of water use through for example diet description or broader optimization of water allocation between different water uses by incor- 
porating access to external water resources through virtual water trade [10]. This presents the concept as a practical policy tool that can be extended to detailed analysis of water resources management; as well as; environmental, agricultural, and trade policies. Until now many of these policy issues have been solved empirically by common sense food policies and strategies in many Arab countries. Some of these countries like Jordan have made policy choices to reduce or abandon exports or local production of water intensive crops and replace them by imports or higher return crops to allow optimization of water use.

Issues related to virtual water trade were clearly outlined in several reports $[4,10]$. These issues fall into the following categories: food security, environment conservation, employment and poverty, geopolitics, pricing and subsidies, investment in trade infrastructure, and diet change. It is thus important to investigate these issues before we jump to conclusions about the suitability of virtual water trade as a policy option. This paper is primarily concerned with investigating the prevailing water/food situation in the Arab states and possibility of using "Virtual Water Trade" as a remedy policy. The investigation includes outlining water and food security facts and figures, in addition to policy measures undertaken to overcome any insecurities; followed by an assessment of potential water savings in some Arab states in the event of considering virtual water as a policy options.

\section{THE PRACTICAL VALUE OF THE VIRTUAL WATER CONCEPT}

The virtual water concept has basically two major types of practical use.

\subsection{Virtual Water Trade as an Instrument to Achieve Water Security and Efficient Water Use}

Net import of virtual water in a water-scarce nation can relieve the pressure on the nation's own water resources. Virtual water can be seen as an alternative source of water. Using this additional source can be an instrument to achieve regional water security. More firmly stated, and this is the political argument that has been put forward by Tony Allan from the beginning of the virtual water debate, virtual water trade can be an instrument in solving geopolitical problems and even prevent wars over water $[12,13]$. Next to the political dimension, there is the economic dimension, equally stressed by Allan [14-16]. The economic argument behind virtual water trade is that, according to international trade theory, nations should export products in which they possess a relative or comparative advantage in production, while they should import products in which they possess a comparative disadvantage [17].

Hoekstra and Hung [18,19] argue that while pricing and technology can be means to increase local water use efficiency and reallocating water at basin scale to its higher-value alternative uses a means to increase water allocation efficiency-virtual water trade between nations can be an instrument to increase 'global water use efficiency'. From an economic point of view it makes sense to produce the water-intensive products demanded in this world in those places where water is most abundantly available. In those places water is cheaper, there are smaller negative externalities to water use, and often less water is needed per unit of product. Virtual water trade from a nation where water productivity is relatively high to a nation where water productivity is relatively low implies that globally real water savings are made.

Virtual water trade between or within nations can be seen as an alternative to real, inter-basin water transfers. This is for instance very relevant for China, where major real water transfer schemes (from the south to the north of China) are being considered. Also in the Southern African region, virtual water trade is a realistic, sustainable and more environmentally friendly alternative to real water transfer schemes [20]. With two Asian examples, Nakayama [21] points out that application of the idea of virtual water trade could seriously impact on the management practice of international river basins. Renault [11] notes that the issue of optimal production is not only a matter of wisely choosing the locations of production, but also a matter of proper timing of production. One can try to overcome periods of water shortage by creating artificial water reservoirs, but as an alternative one can also store water in its virtual form, e.g. by food storage. This can be a more efficient and more environmentally friendly way of bridging dry periods than building large dams for temporary water storage [4].

\subsection{Water Footprints: Making the Link between Consumption Patterns and the Impacts on Water}

The second practical use of the virtual water concept lies in the fact that the virtual water content of a product tells something about the environmental impact of consuming this product. Knowing the virtual water content of products creates awareness of the water volumes needed to produce the various goods, thus providing an idea of which goods impact most on the water system and where water savings could be achieved. Hoekstra and Hung [18] have introduced the concept of the water footprint, being the cumulative virtual water content of all goods and services consumed by one individual or by 
the individuals of one country. In analogy of the ecological footprint [22,23], the water footprint can be a strong tool to show people their impact on the natural resources [4,24,25]

\section{QUANTIFYING THE VIRTUAL WATER CONTENT OF PRODUCTS}

Hoekestra [4] argues that the assessment process of the virtual water content of a product is not an easy task. This is because of the many factors that influence the amount of water used or consumed in a production process. He also enumerated some factors that should at least be considered and provided together with the estimates:

- The place and period (e.g. which year, which season) of production.

- The point of measurement. In case of irrigated crop production, the question is for instance whether one measures water use at the point of water withdrawal or at the field level.

- The production method and associated efficiency of water use. A relevant question is whether water wasted is included in the estimate.

- The method of attributing water inputs into intermediate products to the virtual water content of the final product.

Considering the various studies available, little convergence exists with respect to the general approach taken. Some studies take virtual water content of a product at the production site, other studies consider the hypothetical virtual water content if the product would have been produced at the place where the product is actually consumed. The studies also differ with respect to the point of measurement: some measure at field level, others account for the losses between water withdrawal and application. Zimmer and Renault [26] divided the products with respect to their virtual water content into different categories. These categories are primary products (crops), processed products (such as sugar, vegetable oil and alcoholic beverages), transformed products (including animal products), by-products (such as cotton seeds), multiple products (e.g. coconut trees) and low or non-water consumptive products (e.g. sea fish). Hoekestra and Hung [27] studied the quantification of virtual water trade flows between nations in the period 19951999. The approach they followed was to multiply crop trade flows (ton/year) by their associated virtual water content $\left(\mathrm{m}^{3} /\right.$ ton $)$. Figure 1 illustrates the methodology they used to calculate the global virtual water trade. The following discussion illustrates the role of virtual water as an instrument for water resources management on the global, regional and local levels.

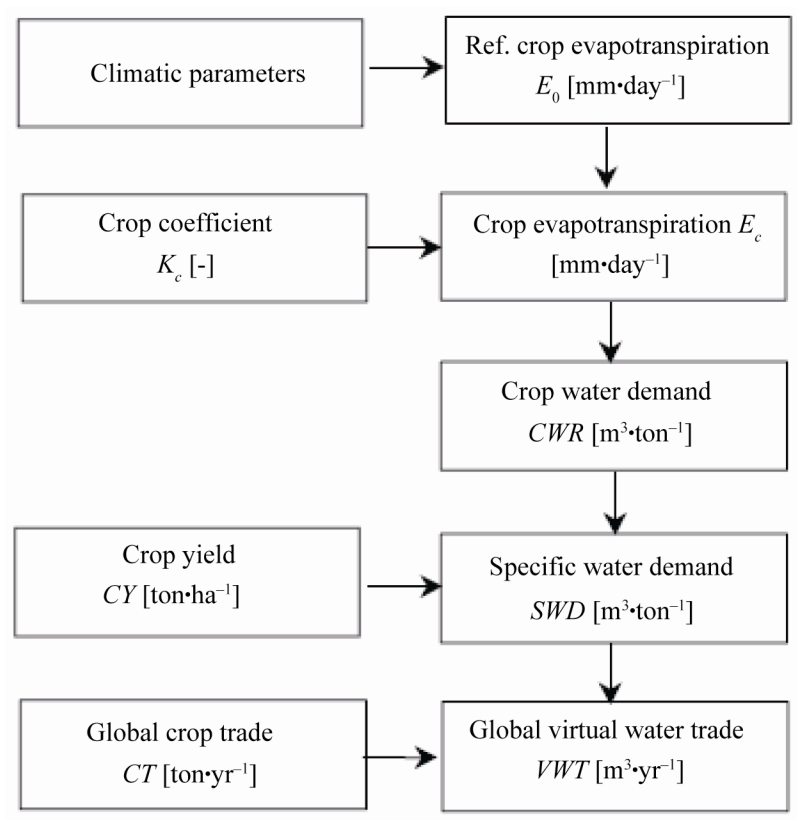

Figure 1. Steps in the calculation of global virtual water trade.

\section{VIRTUAL WATER IMPLEMENTATION PROBLEMS}

Theoretically, the virtual water strategy is a vital solution for water resources problems. Since the main advantage of the virtual water strategy is its redistributive effect on the global level in the form of the international trade of goods and services, this requires a fair and reliable system of international trade. Warner [28] categorized the problems of virtual water strategy into two perspectives: the security and vulnerability perspectives. He argues that virtual water may promote the state of carelessness. This means that because of the invisible nature of the virtual water strategy, policy makers consider it as a secret reserve. So they are not tempted to do any long term oriented plans. Since virtual water bails them out in the short run. Long term plans require investments in technology, social ingenuity and democracy to facilitate a transition to a demand management strategy or reallocation of the resource among users rather than dependence on trade flow. Warner also argues that the importation of cheap grains is like creating food 'reservoir' giving the state a monopoly on the food market, allowing it to create a client base in the major cities distributing food in exchange for political allegiance. Thus the security of the recipient states was enhanced, as well as the allegiance of those states to American foreign goals. This allegiance brings a degree of political dependency some would denounce as neo-colonial.

Vulnerability approach in disaster studies claimed that economical and political power differentials lead to unequal distribution of vulnerability within global and do- 
mestic systems, in turn bringing about the social, political and economic exclusion of the poor and powerless [28]. This vulnerability comes form the increased interdependency of the poor on the powerful states. Also the global food trade is exposed to global market price fluctuations and shocks. Meanwhile in USA and Europe (the biggest producers), agriculture is heavily subsidized at several stages of the production process, lands, inputs, transport, marketing, export and transport. Those who pay subsidies may stop paying and hence raising the world price.

\section{GLOBAL LEVEL}

The concept of virtual water mainly views water as a global commodity [29]. To consider virtual water as a solution for water resources scarcity on the regional level, an answer to the question "is there enough water on this planet for a future global population double its present side?" must be found. In his argument, Allan [13] asserts that the answer is controversial and needs much more research to determine water availability on the global scale. In the demand side, which is completely related to the population growth? The precision of the estimates of the global population varies by over $50 \%$. In this uncertain domain there is space for numerous pessimists and optimists to spin counter interpretations. The International Food Policy Research Institute identifies low, medium and high scenarios for population. These predict respectively 7.7 billion, 9.4 billion and 11.1 billion for the global population by 2200. Allan [13] mentioned that the global hydrological system is evidently in surplus as it is able to meet the most demanding element of global water demand, the global consumption for food. Assuming a medium consumption scenario of 1500 $\mathrm{cm} /$ capita/year, global freshwater needs are about 8.25 $\mathrm{bm}^{3} /$ year. So a consumption of this level is well within the estimates of global freshwater availability. But he argues about the future position and he asserts that there is certainty neither about volumes of freshwater available nor about the capacity to use it effectively. In these circumstances there is evidence to support arguments of both optimists and pessimists. Allan [13] concluded that the world's water and food futures are uncertain but not seriously insecure. Many studies have been conducted to estimate the global virtual water trade. Tables 1-3 are adopted from Hoekstra [4]. The global virtual water trade is given in Figure 2 while Table $\mathbf{4}$ shows the continental virtual water movement.

\section{REGIONAL LEVEL: VIRTUAL WATER IN THE ARAB REGION}

In the regional level, the Arab's hydrological system is
Table 1. Assessment of global virtual water trade between nations (periods 1995-1999) according to the IHE study.

\begin{tabular}{lcc}
\hline $\begin{array}{l}\text { Global virtual water trade (from perspective } \\
\text { of exporting countries) }\end{array}$ & $\begin{array}{c}\text { Volume } \\
\left(\mathrm{bm}^{3} / \mathrm{yr}\right)\end{array}$ & $\begin{array}{c}\text { Percentage } \\
(\%)\end{array}$ \\
\hline - associated with crop trade & 695 & 67 \\
- associated with trade of livestock & 245 & 23 \\
$\quad$ and livestock products & 100 & 10 \\
$\begin{array}{l}\text { - associated with trade of industrial } \\
\text { products }\end{array}$ & 1040 & \\
Total & & \\
\hline
\end{tabular}

Table 2. Assessment of global virtual water trade between nations (in 2000) according to the WWC-FAO study.

\begin{tabular}{lcc}
\hline $\begin{array}{l}\text { Global virtual water trade (from per- } \\
\text { spective of importing countries) }\end{array}$ & $\begin{array}{c}\text { Volume } \\
\left(\mathrm{bm}^{3} / \mathrm{yr}\right)\end{array}$ & $\begin{array}{c}\text { Percentage } \\
(\%)\end{array}$ \\
\hline $\begin{array}{l}\text { - associated with trade of } \\
\text { vegetal products }\end{array}$ & 795 & 60 \\
- associated with trade of & 180 & 13 \\
$\quad \begin{array}{l}\text { animal products } \\
\text { - associated with trade of meat }\end{array}$ & 173 & 13 \\
- associated with trade of fish & 192 & 14 \\
$\quad \begin{array}{l}\text { and sea food } \\
\text { Total }\end{array}$ & 1340 & \\
\hline
\end{tabular}

Table 3. Assessment of global virtual water trade between nations (in 2000) according to the Japanese study.

\begin{tabular}{lcc}
\hline $\begin{array}{l}\text { Global virtual water trade (from } \\
\text { perspective of exporting countries) }\end{array}$ & $\begin{array}{c}\text { Volume } \\
\left(\mathrm{bm}^{3} / \mathrm{yr}\right)\end{array}$ & $\begin{array}{c}\text { Percentage } \\
(\%)\end{array}$ \\
\hline 一 associated with trade of cereals & 472 & 69 \\
— associated with trade of soybean & 84 & 12 \\
—associated with trade of meat & 127 & 19 \\
Total & 683 & \\
\hline Global virtual water trade (from & Volume $\left(\mathrm{bm}^{3} / \mathrm{yr}\right)$ & Percentage \\
perspective of importing countries) & & 76 \\
\hline - associated with trade of cereals & 868 & 10 \\
- associated with trade of soybean & 118 & 13 \\
-associated with trade of meat & 152 & \\
Total & 1138 & \\
\hline
\end{tabular}

Table 4. Continental virtual water movement

\begin{tabular}{|c|c|c|c|}
\hline & $\begin{array}{c}\text { Exporter virtual } \\
\text { water }\left(\mathrm{km}^{3}\right)\end{array}$ & & $\begin{array}{c}\text { Importer virtual } \\
\text { water }\left(\mathrm{km}^{3}\right)\end{array}$ \\
\hline \multirow{6}{*}{ North America } & 78 & East Asia & 154 \\
\hline & 32 & Central America & 68 \\
\hline & 25 & North West Africa & 62 \\
\hline & 20 & Middle East & 58 \\
\hline & 14 & West Europe & 20 \\
\hline & 30 & Others & 74 \\
\hline \multirow{5}{*}{ South America } & 32 & West Europe & 30 \\
\hline & 23 & East Asia & 28 \\
\hline & 20 & Middle East & 38 \\
\hline & 14 & North West Africa & 24 \\
\hline & 19 & Others & 42 \\
\hline \multirow{4}{*}{ Oceania } & 10 & East Asia & 23 \\
\hline & 11 & South East Asia & 28 \\
\hline & 12 & Middle East & 16 \\
\hline & 15 & Others & 26 \\
\hline
\end{tabular}

definitely less and less able to meet the rising demands being placed upon it. Allan argues that the insecurity of the Middle East and North Africa (MENA) not just from its poor water resources endowment. The water endowment is a significant factor, but much more important is 


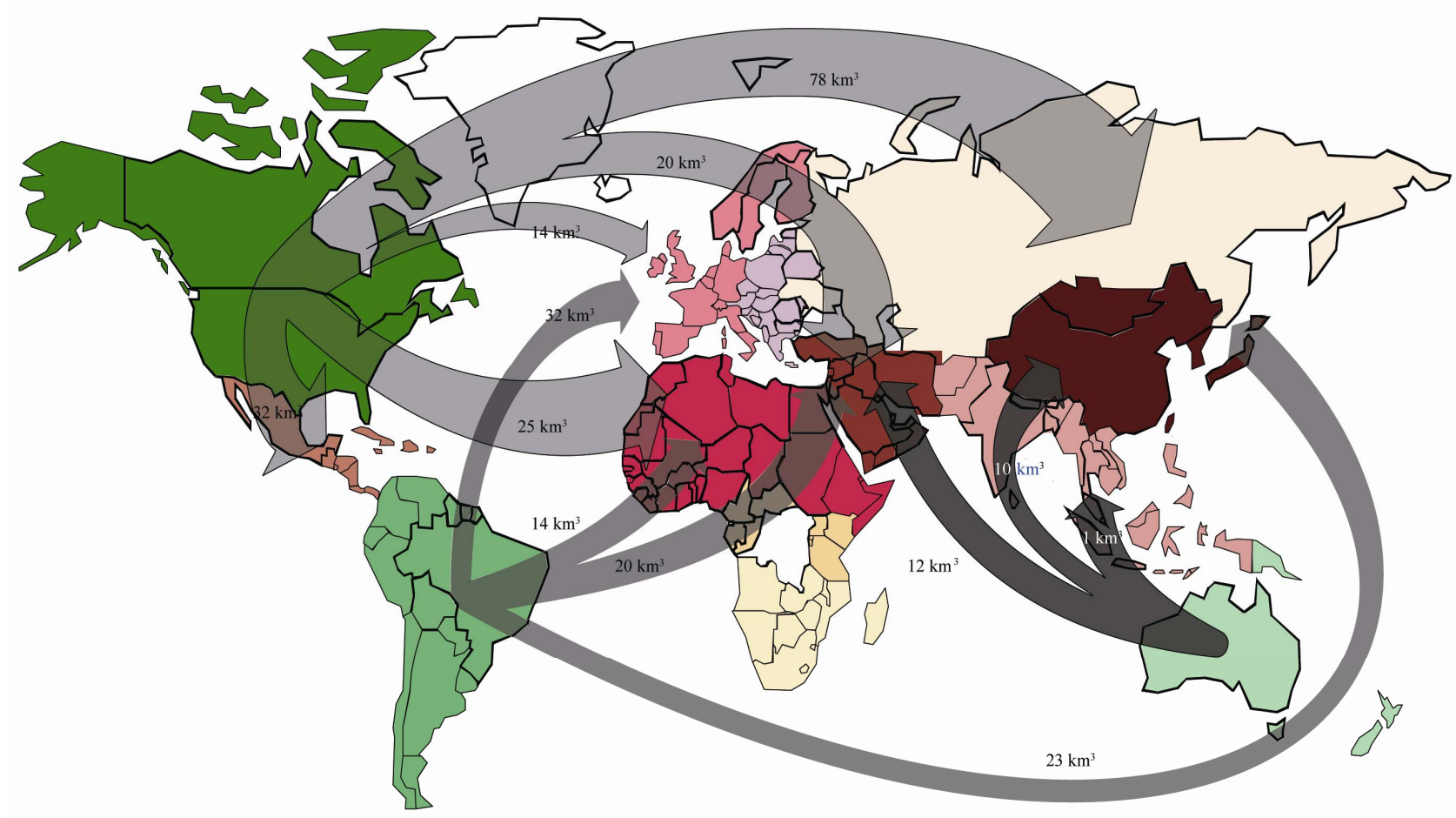

Figure 2. Global virtual water trade.

the capacity of its agriculture sectors, its governments and international institutions to adapt to the resource scarcity and to take measures to find and mobilize substitutes. Allan stated that, "the pattern of trade indicates that the MENA virtual water imports vastly exceed exports. By the mid-1980s MENA grain and flour imports had risen rapidly from about seven million tones per year in the early 1970s to over 40 million tones by the mid-1980s. This volume was equivalent to about 20 per cent of the regions total freshwater use by the late twentieth century. At the 1000 cubic meters of water per tone of grain estimate of water content the regional imports of virtual water by the mid-1980s were equivalent to the annual flow of the Nile into the Egyptian agricultural sector. The demographic trends of the region point to a doubling of population by about 2030. Taking into account possible improvements in water productivity in MENA agriculture the need to import water intensive staple food commodities will remain. It is likely that the imports of virtual water will increase four or five-fold by 2030.

\subsection{Agriculture and Food Production in the Arab States}

Population growth in the Arab countries is the major factor for the increase in food consumption; such growth has almost doubled between 1970 and 1990; and the projections for the future growth are even more alarm- ing. The population growth rate is among the highest is the world. In addition, the economic development and the change in aspirations and standard of living due to the oil revenues in the last few decades lead to a very high percentage of immigration to the Arab oil rich countries. The total population is expected to continue increasing and to reach 450 million by 2030 .

The high rate of population growth in the region caused food security fears to loom large in public policy discussions in Arab region [30,31]. Food security may be analyzed for units at different conceptual levels: regions, countries, households, and individuals. Much analysis of the topic has focused on the macro level: food production in the region as a whole (and most of its countries) falls far short of food requirements, making it necessary for most countries to turn to imports for a large share of domestic food consumption. As a result, the ability of most countries to maintain national food security depends on import capacity.

\section{Agriculture policies}

In the past 20 years the Arab countries were aiming to achieve greater food self-sufficiency and accordingly the majority of Arab countries provided generous subsidies to the agricultural sector. Given the arid climate of these countries, production can only be increased by increasing the area of land under irrigation, by improving irrigation efficiency, or a combination of the two. Agricultural subsidies are given in several forms, for wells, canals, 
fuel, and other inputs, price support programs, trade protection in some countries, and lack of controls on groundwater extraction or charges. These subsidies increased the irrigated areas drastically and are contributing to the depletion of aquifers. Besides, these subsidies distort costs and revenues, and many of the agricultural activities in the Arab countries are financially profitable only because of Government subsidies and incentives. Subsidization is often adopted to encourage agricultural practices for environmental, economic and cultural reasons; however, in countries with water shortage mostly cultural reasons are the drivers for subsidization. Although agriculture consumes about $80 \%$ - 90\% of the available water in most Arab countries, it contributes for less than $10 \%$ of Gross Domestic Product (GDP) in most of the countries.

The employment in the agricultural sector as a proportion of total employment in 2003 ranged from 1 percent in Kuwait, Bahrain, and Qatar to 58 percent in Sudan. Nevertheless, subsidization has played a role in increasing agriculture water use efficiency in many Arab states, and is thus justified as a water demand management tool; an example is Egypt's Irrigation Improvement Project.

\subsection{Water Resources in the Arab Region}

The Arab world draws its water resources from rainwater; rivers and underground water sheets as well as sources that are non-conventional (desalinated water and treated waste water). The quantities that can be obtained from these sources differ widely from one country to another and from one location to another within a single country; rainfall is inexistent in some countries and heavy in others, for example (over one thousand billion cubic meters per year in Sudan). Countries such as $\mathrm{Su}-$ dan, Egypt, Syria, Iraq, Lebanon, Jordan and Morocco have large and small rivers but other Arab countries have neither rivers nor lakes. Where water resources are rare and financial resources permit the abundant water found underground is exploited (the East Al Jazira underground sheet covering 1.6 million sq. $\mathrm{km}$. and the Nubian underground sheet covering 2 million sq. $\mathrm{km}$.). Other nonconventional sources are being promoted, with the result that the Arab countries are in the forefront of the development of water desalination techniques, producing over 5 million cubic meters a day, that is, over $70 \%$ of world production.

\subsection{Water Demand and the Need for Sustainability Measures}

The progressing developments and water policies in the Arab countries resulted in the current difficult water shortage situation. The huge amounts of water used for irrigated agriculture are leading to abstracting large amounts of the nonrenewable "fossil" groundwater. This creates real threats for the sustainability in the whole region. In order to restore and/or improve this imbalance, focus should be given mainly to reductions of demands from the agricultural sector, and also to create additional sources of water to reduce groundwater abstractions. Achieving these objectives needs considerable efforts to reform both water and agricultural policies and also significant cost to enhance the capacity of wastewater treatment as a safe and reliable source of water for irrigation.

The need for water and agriculture policy reform

It is vital that a number of steps be taken to economize on water consumption and protect water resources from over-abstraction and pollution. Policy reforms will need to focus on both supply and demand management aspects of water management. The water management mission will have to consider guaranteeing consistent supply (infrastructure: dams, reservoirs, water re-use, and non-conventional methods: e.g. desalination); prioritizing water use (drinking water versus irrigation), as well as, managing, allocating and monitoring water use (e.g. legal/technical regulations and pricing).

Agricultural policies in the Arab countries also need to be reformulated to serve the purpose of increasing efficiency and conserve the already depleted water resources. Often agricultural policy reform aims to: conserve water resources; preserve water quality; and improve crop water productivity. The notion of "more crop per drop" has been adopted by several Arab states as part of a general recognition of the importance of rationalizing water use. It is however being called upon by researchers and scholars to adopt the notion of "more livelihood per drop" which puts water resources in the context of the greater goal of any national policy which is "securing better livelihood". Targeting this ultimate goal one can argue that agriculture policy reforms should consider limiting subsidies to technologies which promote water conservation; whether the focus is on developing salt-tolerant and drought-resistant crops or on using more efficient irrigation techniques. In addition, other policy aspects that can have an even greater impact in a short period are related to promoting a marketoriented policy through the cultivation of crops with high water productivity and low-water content; and thus import crops with high water content (virtual water). The choice here is whether to increase integration with the global market or to focus on regional integration opportunities. 


\subsection{Virtual Water Trade in the Arab Region}

Having established the need for policy reform in water consuming activities, and by outlining some of the issues related to virtual water trade, it is important to investigate the options provided by the virtual water trade concept and the suitability of such options to the Arab region. Local planning and regional collaboration incorporating the notion of virtual water trade could result in: 1) exchange of goods, 2) diversification of crops, or 3) crop replacement actions for any country.

\section{Virtual water policy dimensions}

More often than not, scholars in the Arab region contradict the political argument that has been put forward by Tony Allan from the beginning of the virtual water debate, that virtual water trade can be an instrument in solving geopolitical problems and even prevent wars over water $[12,13]$. The contradiction is simply based on the perception that food exporting countries are mostly western countries, and the relationship between the Arab states and western countries is dominated by skepticism and fear of domination. Thus, looking at the bigger picture it is perceived by the Arab states that by depending on food imports they are giving in to foreign domination.

Next to the political dimension, there is the economic dimension, equally stressed by Allan [14-16]. The economic argument behind virtual water trade is that, according to international trade theory, nations should export products in which they possess a relative or comparative advantage in production, while they should import products in which they possess a comparative disadvantage [17]. Hoekstra and Hung [18,19] argue that virtual water trade between nations can be an instrument to increase 'global water use efficiency'. From an economic point of view it makes sense to produce the waterintensive products demanded in this world in those places where water is most abundantly available. In those places water is cheaper, there are smaller negative externalities to water use, and often less water is needed per unit of product. Virtual water trade from a nation where water productivity is relatively high to a nation where water productivity is relatively low implies that globally real water savings are made.

However, a major source of skepticism is whether or not a fair and secure trade with water-abundant nations can be sustained in an ever changing trade environment. An advantage for the Arab countries is that they export enough to earn the foreign exchange required to purchase the food imports they need. The second issue pertains to the level of the economic base i.e. whether the economy of the country is well developed and diversified to take the decision of reallocating water from cereals, which provide subsistence living to large sections of rural population, to a more economically rewarding wa- ter use.

Regional cooperation on this subject is of paramount importance as it would allow countries of the region to assess and analyze the situation on a broader basis, taking into consideration common strategic issues. It would further alleviate many of the political and economic concerns. Eyes have been often directed to Sudan as the potential food basket for the Arab states due to the abundance of water resources and arable lands there. However, political instability is a barrier to taking advantage of such a golden opportunity.

Aside from the economic and political aspects of virtual water trade; growing one's food (i.e. feeding oneself) has other important aspects; the cultural and social aspects are of major influence on the decision whether or not to grow a certain crop, furthermore culture interferes with the whole acceptance of the notion of virtual water trade.

\section{The need for cultural change}

In general, as Mahmoud Abu-Zeid [32], former president of the World Water Council notes: "The cultural and socio-economic values of water are still a very elusive subject. Several learned meetings stressed the economic value of water, while others stressed its social and cultural values. The importance of one or the other will vary from one society to another and from time to time, depending on the specific historical background, cultural heritage, extent of fresh water availability and the socioeconomic conditions of the concerned region. Developing a unified approach is required, with clearly defined associated conditions and limitations for its applicability, which should accommodate the diversity of the world's regions [32]. Changing people's habits and the way they use and perceive water is a challenge that involves changing deep-rooted attitudes held by individuals, institutions, water professionals and civil society organizations. Social change of this kind can be brought about by the application of appropriate tools [33]. Hoekstra [34] investigated four cultural perspectives of appreciating water which represent the four ways of life described as the hierarchist, egalitarian, individualist and fatalist. These perspectives are presented herein from the aspect of water trade.

In the context of virtual water trade the different cultural perspectives have different attitudes that range from perceiving water trade as only possible for the rich people in power and do not benefit the poor (the fatalists); to perceiving water as an economic good that should be managed as such, and thus free trade is the ultimate solution to carry water and water-intensive products to the demand areas (the individualists). On the Other hand, the hierarchists regard scarcity as a supply problem; where inter-basin or international trade of water is a possible 
way of improving the allocation of water, but it is seen as an issue to be regulated by governments rather than by free enterprise, due to the public character of water. Whereas, egalitarians consider water trade in any form undesirable, because water is seen as public property. Importing or exporting water-intensive products (trade in virtual water) is undesirable as well. Instead countries should strive for water and food self-sufficiency through demand management.

In the previous, it has been demonstrated that many of the current controversies among water researchers and policy makers can be explained from the existence of different cultural perspectives. These perspectives differ in their underlying basic values, beliefs and assumptions. Hoekstra [34] stressed that current scientific knowledge does not provide sufficient argument in favor of one particular perspective. One reason is that uncertainties about the various interactions between man and the environment are still very large, leaving room for different interpretations of the available data. Another reason is that most of the water problems of today are not merely technical but strongly value-laden. Therefore it would be advisable to create a culture mixture when studying the feasibility of virtual water trade as a policy option in the Arab region. Such a cultural mixture is needed when considering other policies concerning water planning and use. In addition, this mixture would create a balance between the interests of the different groups of a society and insure a lasting "sustainable" planning strategy.

\section{Water savings by virtual water trade}

The most straightforward effect of virtual water is about water savings for the country or the region that imports food products. The savings are directly the result of the quantity of imports multiplied by the local virtual water values according to the equation below [9]:

Water savings $\left(\mathbf{m}^{3}\right)=\operatorname{Import}($ ton $) \times \mathbf{V W V}_{\text {consmp. site }}(1)$ where $\mathrm{VWV}_{\text {consmp.site }}=$ Virtual water value per crop $\left(\mathrm{m}^{3} /\right.$ ton $)$ if produced at the point of consumption

In the case of Arab countries, and since all crops are grown by irrigation, the water savings attained by crop importing are always real. Whereas other countries that have some rain fed agriculture might not benefit from the calculated water savings as it might not be possible to put the saved rainwater to other use. Thus in extremely dry countries like Arab countries, one can assume that importing food will save water that otherwise would be needed to irrigate crops. Therefore the value $\mathrm{VWV}_{\text {consmp. site }}$ could be calculated as:

$$
\mathrm{VWV}_{\text {consmp. site }}=\mathbf{I W R} / \mathrm{Y} \text { irrigated }
$$

where:

$-\mathrm{VWV}_{\text {consmp. site }}=\mathrm{VW}$ value of irrigated crop $\left(\mathrm{m}^{3} /\right.$ ton $)$

$-\mathrm{IWR}=$ Irrigation water requirements $\left(\mathrm{m}^{3} / \mathrm{ha}\right)$
- $\mathrm{Y}=$ Crop yield under irrigated circumstances (ton/ha)

The irrigation requirements are calculated on a decade basis by calculating potential crop evapotranspiration minus effective rainfall.

For example, there is a trend of increase in water consumption in producing primary crops in the Gulf Cooperation Council (GCC) countries (cereals, fruits, and vegetables), during the period from 1980-2003 the GCC countries have consumed substantial amounts of water. Virtual water value of irrigated crops are taken on average basis for these countries from the footprints tables (cereals: $2500 \mathrm{~m}^{3} /$ ton, fruits: $3000 \mathrm{~m}^{3} /$ ton, vegetables: $2900 \mathrm{~m}^{3} /$ ton).

Figure 3 shows the virtual water import in the Arab countries while the virtual water import embodied in the food import (cereal, oil and sugar) to the Arab region is shown in Figure 4.

\section{NATIONAL LEVEL: ROLE OF VIRTUAL WATER IN EGYPT}

Egypt as one state of the Arab region shares as well as water scarcity problem the political characteristics of the region. In his analysis of the different water policies, Allan [16] identifies three policies for managing water resources with different ranking aspects. The ranking or priority of the policies depends on the viewer, outsider professionals or insiders governments (politicians). The policies are as follows:

1) Achieving improved water use efficiency by implementing measures of productive efficiency to improve returns to water at farm level and irrigation level and also by urban and drainage reuse.

2) Applying principles of demand management to improve allocative efficiency and returns to water. This is done at farm level by raising water efficient crops, intersectoral re-allocation and international re-allocation.

3) Achieving strategic water security. By securing supplies of "virtual water" by international regional cooperation in the international food trade.

The above ranking is the one adopted by politicians and governments. The reverse of that ranking with the virtual water policy on the top is the one adopted by external professionals (outsiders) who are concerned mainly by the economy and the environment in contrast to politicians whose main interest is the political stability.

Some criticisms on virtual water are also worth noting. The most common ones are that the poor countries cannot afford virtual water import and virtual water import makes the receiving country dependent upon the international market [2]. These criticisms have been often voiced loudly at international meetings, workshops and on other national and international occasions. The criti- 


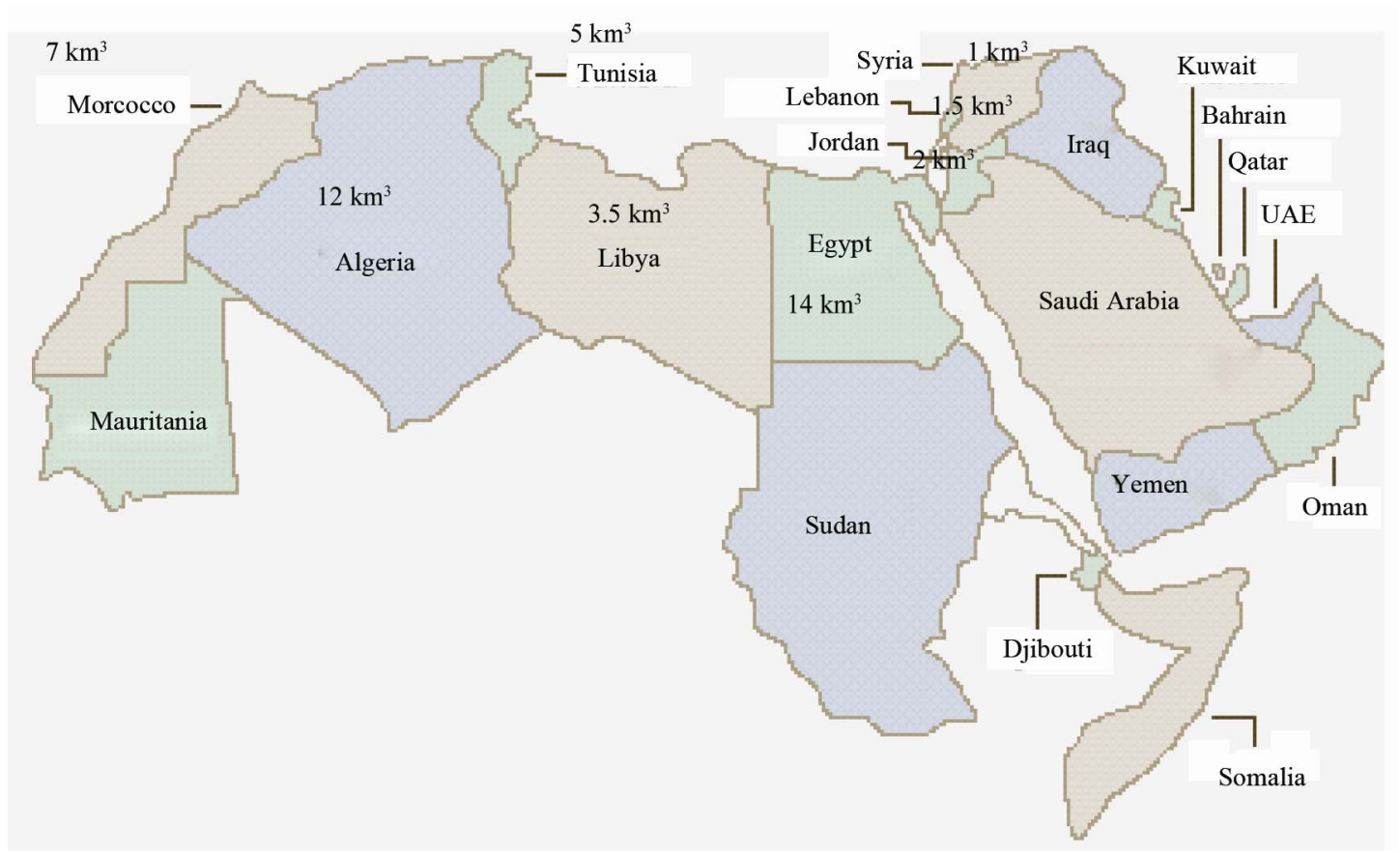

Figure 3. Virtual water import in the Arab countries.

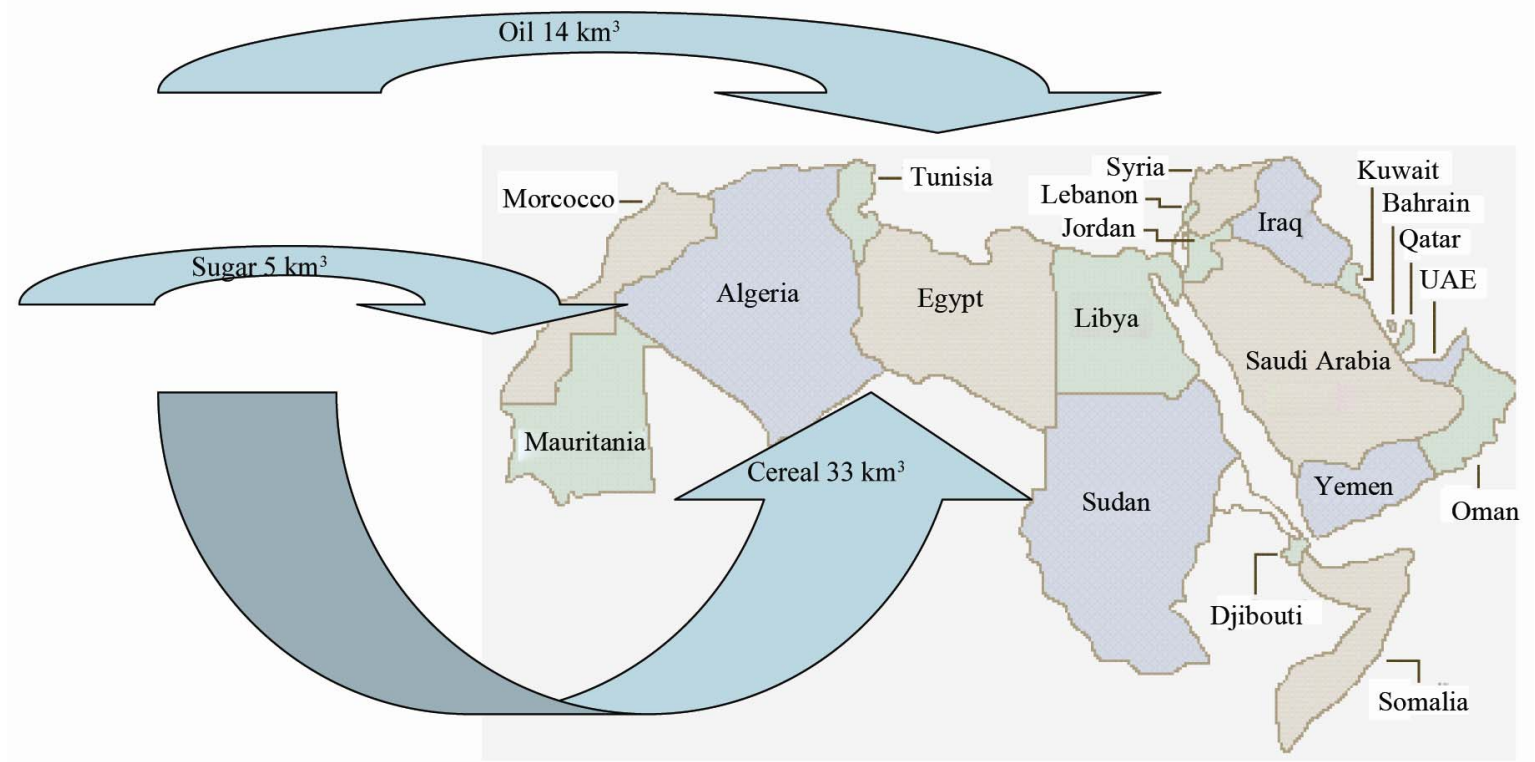

Figure 4. Virtual water import embodied in the food import (cereal, oil and sugar) to the Arab region.

cisms may be understandable, but do not quite touch the point. Virtual water by its origin describes the fact that many water scarce countries are importing (although often unconsciously) a large portion of their food which has effectively and silently reduced the domestic water demand for food production that otherwise would be needed. The situation implies that when water is in absolute scarcity, virtual water import is necessary.

Water, an indispensable commodity for life of all be- ings and for the development and well being of human societies, has a finite nature of availability at global, regional and national territorial theaters. The need for it, at individual and national levels is not as finite, but is rather ever-increasing prompted by improved technological deliveries and uses; by improved incomes that enhanced better living standards, and by the net growth in the levels of population at national levels. Coupled with management challenges at individual, national and 
regional levels, the water challenges have become serious and at times insurmountable if faced in absence of cooperation at national, regional and, indeed, international levels [6].

One of the major indicators of the scale of the water deficit of water scarce countries is the level of its food imports. The reason food imports are such a strong indicator of water deficit is that the water required to grow food is what an economist would refer to as the dominant consumptive use of water. The use is dominant whether viewed from the point of view of the individual citizen or the national economy. Water used in the agricultural sector exceeds by ten times the water used by the industrial and municipal sectors combined [14]. The main challenge facing Egyptian national development is limited water resources. Water is the main factor, which determines the type, size and location of any economic activity. Egypt is a very arid country, where the average annual rainfall seldom exceeds $200 \mathrm{~mm}$ along the northern coast. The rainfall declines very rapidly from the coastline to the inland areas, and becomes almost nil south of Cairo. This meager rainfall occurs in the winter in the form of scattered showers, and cannot be depended upon for extensive agricultural production. Thus, reliable availability of irrigation water is a necessary condition for agricultural development. In Egypt, about $85 \%$ of the water resources are consumed in the agriculture sector. It is thus important to investigate these issues before jumping to conclusions about the suitability of virtual water trade as a policy option. This section is primarily concerned with investigating the prevailing water/food situation in Egypt. The investigation includes outlining water and food security facts and figures, as well as policy measures undertaken to meet the challenges.

\subsection{Water Resources in Egypt}

The main and almost exclusive source of surface water in Egypt is the River Nile. The 1959 agreement between Egypt and Sudan was based on the average flow of the Nile during the period 1900-1959. The average annual flow at Aswan during that period was 84 billion $\mathrm{m}^{3}$. The average annual evaporation and other losses in Lake Nasser were estimated as 10 billion $\mathrm{m}^{3}$, leaving a net usable annual flow of 74 billion $\mathrm{m}^{3}$. Under the 1959 treaty, 55.5 billion $\mathrm{m}^{3}$ were allocated to Egypt and 18.5 billion $\mathrm{m}^{3}$ to the Sudan. The High Aswan Dam was constructed in 1968 to assure the long-term availability of water for both countries. Its lake has a live storage capacity of 130 billion $\mathrm{m}^{3}$. The annual discharges from the High Dam Lake during the period 1968 to 2000 are 67.6 billion $\mathrm{m}^{3}[35]$.

\subsection{Food Production in Egypt}

There are three estimates of the virtual water balance in Egypt quoted from Hoekstra [4]; gross virtual water import; gross virtual water export; and net virtual water import. Also a time series for the import of the main cereal crops are illustrated in Figures 5(a)-(f). As with the increase in population in the future, the projected water demand based on some models is about 92 billion $\mathrm{m}^{3} /$ year. If the estimated total water resource availability of about 70 billion $\mathrm{m}^{3} /$ year and taking into consideration that the 70 billion $\mathrm{m}^{3} /$ year is the overall water availability after applying the different measures such as extensive drainage reuse and groundwater full utilization, we can obviously see that the virtual water policy option is pivotal and vital.

\section{CONCLUSIONS}

Different water management policies and strategies have been applied in Arab over time. During the past water abundant periods, supply management (construction of dams, water distribution networks etc.) has been applied. A review of the Virtual Water comparative advantages and related concepts such as water footprints was conducted. Issues related to the assessment of virtual water content of commodities and studies on virtual water trade in the global level were reviewed. The practical value of the virtual water concept as well as the possibility of the application of the concept in the regional and national level was also discussed. The paper emphasizes on the application of virtual water in agriculture products and virtual water trade of these products.

Politicians must be approached to get clear and very well studied approaches about the practical application of virtual water without their approval; and blessing water concepts can not be achieved. There is a possibility for the application of the virtual water concept on the national level taking into account water endowments, and other natural and social economic conditions. The virtual water strategy seeks ways to consciously and efficiently utilize the internal and external water resources to alleviate water scarcity in Arab Region. This, however, by no means implies that importing food is the only response the water scarce countries and regions should and can take. Other measures concerning the supply and demand sides of water management are imperative. The argument here is that the virtual water strategy should be an integral component in the whole package of integrated water resources management. The introduction of virtual water concept as a policy option in Arab Region is still in need for extensive investigations, research, and feasibility evaluation. Nowadays, Arab countries are counted among those water-poor 


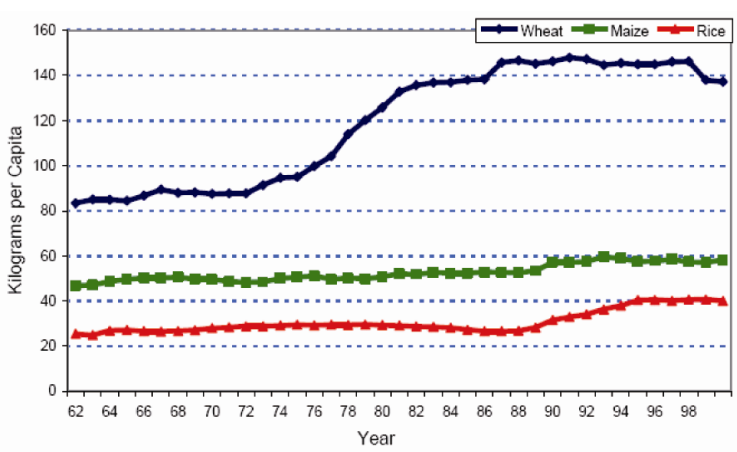

(a)

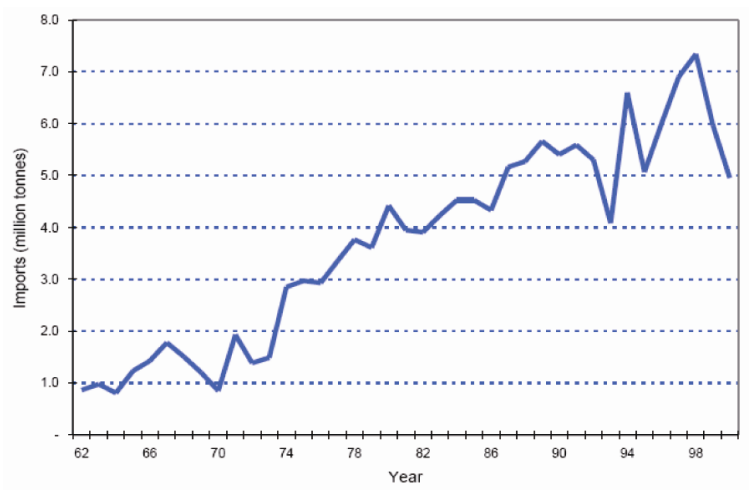

(c)

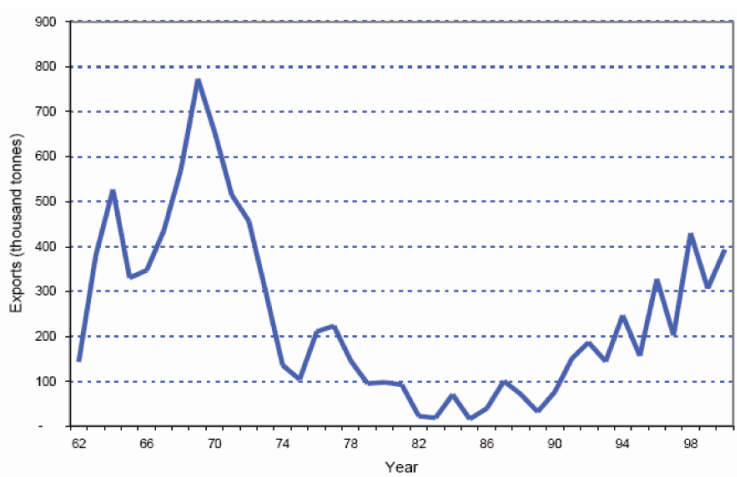

(e)

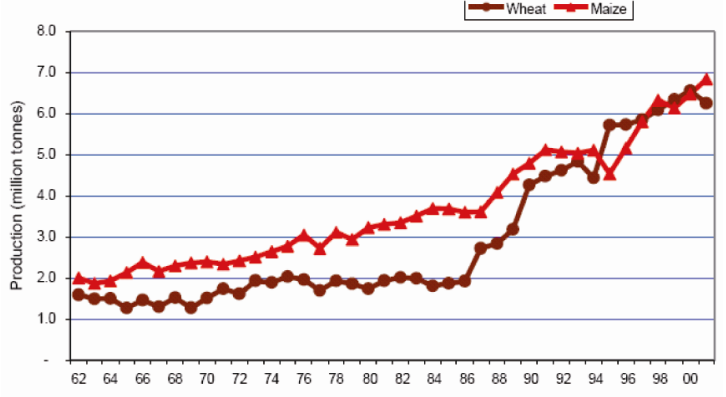

Year

(b)

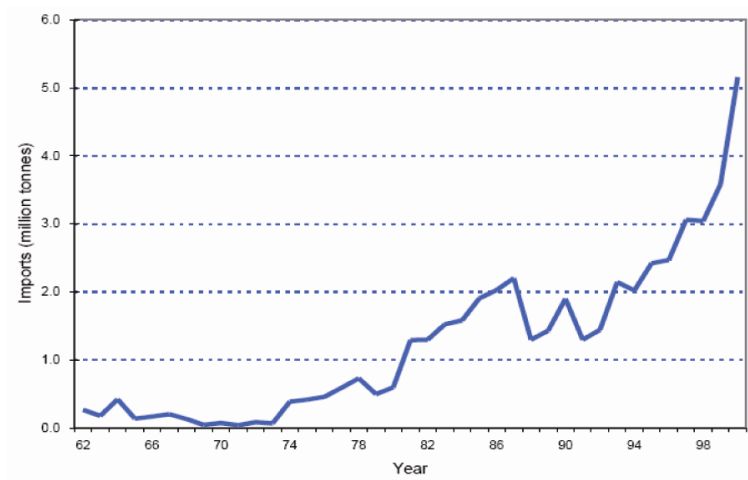

(d)

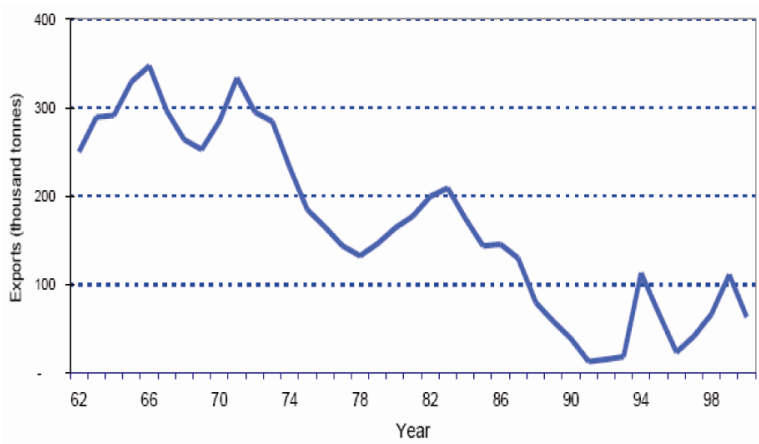

(f)

Figure 5. (a) Per Capita Food Supplies in Egypt, 1962-2000; (b) Production of Wheat and Maize in Egypt, 1962-2000; (c)Wheat Imports to Egypt, 1962-2000; (d) Maize Imports to Egypt, 1962-2000; (e) Rice Exports from Egypt, 1962-2000; (f) Cotton Exports from Egypt, 1962-2000.

countries. This situation is mainly due to its limited fresh water resources and continuous increase in water requirements. As a consequence, Arab Region relies more and more on new technologies and appropriate policies that support the implementation of the integrated water resources management concept.

For Arab Region, it is not the problem of affordability of applying the virtual water concept, but more the problem of priority and independency related to food security. For example, if limited resources of Arab Re- gion were used as production input in high-value crops such as horti-culture instead of low-value and water intensive crops such as cotton or rice, it could increase the value of the input water. Increasing the water used in industry (textiles for example) would also increase the output of water use since it produces manufactured goods that are usually considered step forward on development scale. In order to adopt the application of virtual water concept in the national water resources strategy of Arab countries, there is a need for a clear 
vision and understanding of its advantages and disadvantages according to the Arab conditions. Eventually, there are many other aspects in the balance equation of virtual water concept that limit its applicability in Arab Region. The virtual water aspects need to be subject to extensive research investigation, and analysis. Although import of virtual water trade will relive the pressure on the national water resources, including this new concept as a policy option in Arab requires further research and understanding of the impacts on the local social, economic, environmental, cultural, natural, and political situation. From the previous analysis it is important to point out several points:

1) Food imports are ongoing and imperative for compensating water resource deficiency in the Arab Region, thus there is no point in opposing the concept of using food imports as a complementary factor in the food security formula;

2) In short, the concept of virtual water is well founded, provided countries have more transparent picture of its comparative advantage and accordingly they can translate it into a competitive advantage.

3) It is imperative that planners tackle the sources of skepticism related to political, economic, and sociocultural dimensions of the virtual water trade through the potential of regional integration before introducing it as a policy option; and

Cultural and behavioral changes are necessary for adapting to the current water scarce situation. Nevertheless, a cultural mix would benefit the study of virtual water as a policy option to provide a holistic rather a directed assessment of the issue.

\section{REFERENCES}

[1] Velazquez, E. (2007) Water trade in Andalusia. Virtual water: An alternative way to manage water use. Ecological Economics, 63, 201-208. doi:10.1016/i.ecolecon.2006.10.023

[2] El-Sadek, A. (2010) Virtual water trade as a solution for water scarcity in Egypt. Water Resources Management, 24, 2437-2448. doi:10.1007/s11269-009-9560-9

[3] Rijsberman, F. (2006) Water scarcity: Fact or fiction? Agricultural Water Management, 80, 5-22. doi:10.1016/j.agwat.2005.07.001

[4] Hoekstra, A.Y. (2003) Virtual water: An introduction. Proceedings of the International Expert Meeting on Virtual Water Trade, Delft, Value of Water Research Report Series No. 12.

[5] Horlemann, L. and Neubert, S. (2006) Virtual water trade: A realistic concept for resolving the water crisis? German Development Institute, Bonn, Germany.

[6] Haddadin, M.J. (2003) Exogenous water: A conduit to globalization of water resources. Proceedings of the International Expert Meeting on Virtual Water Trade, Delft, Value of Water Research Report Series No. 12.

[7] Allan, J.A. (1993) Fortunately there are substitutes for water otherwise our hydro-political futures would be impossible. In: ODA, Eds., Priorities for Water Resources Allocation and Management, ODA, London, 13-26.

[8] Allan, J.A. (1994) Overall perspectives on countries and regions. In: Rogers, P. and Lydon, P., Eds., Water in the Arab World: Perspectives and Prognoses, Harvard University Press, Cambridge, 65-100.

[9] Hoekstra, A.Y. and Chapagain, A.K. (2004) Water footprints of nations, Proceedings of the International Expert Meeting on Virtual Water Trade, Delft, Value of Water Research Report Series, No. 16.

[10] World Water Council (WWC) (2004) Virtual water trade-Conscious choices. E-Conference Synthesis. http:// www.worldwatercouncil.org/index.php

[11] Renault, D. (2003) Value of virtual water in food: Principles and virtues. Proceedings of the International Expert Meeting on Virtual Water Trade, Delft, Value of Water Research Report Series, No. 12.

[12] Allan, J.A. (1998) Virtual water: A strategic resource. Global solutions to regional deficits. Groundwater, 36, 545-546. doi:10.1111/j.1745-6584.1998.tb02825.x

[13] Allan, J.A (2003) Virtual water eliminates water wars? A case study from the Middle East. Proceedings of the International Expert Meeting on Virtual Water Trade, Delft, 137-145.

[14] Allan, J.A. (1997) Virtual water: A long term solution for water short Middle Eastern economies? British Association Festival of Science, University of Leeds.

[15] Allan, J.A. (1999) Water stress and global mitigation: Water food and trade. Arid Lands Newsletter No. 45. http://ag.arizona.edu/OALS/ALN/aln45/allan.html.

[16] Allan, J.A. (2001) The Middle East water question: Hydropolitics and the global economy. I.B. Tauris, London.

[17] Wichelns, D. (2001) The role of virtual water in efforts to achieve food security and other national goals, with an example from Egypt. Agricultural Water Management, 49, 131-151. doi:10.1016/S0378-3774(00)00134-7

[18] Hoekstra, A.Y. and Hung, P.Q. (2002) Virtual water trade: A quantification of virtual water flows between nations in relation to international crop trade. Proceedings of the International Expert Meeting on Virtual Water Trade, Delft, Value of Water Research Report Series No.11.

[19] Hoekstra, A.Y. and Hung, P.Q. (2003) Virtual water trade: A quantification of virtual water flows between nations in relation to international crop trade. Proceedings of the International Expert Meeting on Virtual Water Trade, Delft, Value of Water Research Report Series No. 12.

[20] Earle, A. and Turton, A. (2003) The virtual water trade amongst countries of the SADC. Proceedings of the International Expert Meeting on Virtual Water Trade, Delft, 183-200.

[21] Nakayama, M. (2003) Implications of virtual water concept on management of international water systemsCases of two Asian international river basins. Proceedings of the International Expert Meeting on Virtual Water Trade, Delft, 237-239.

[22] Wackernagel, M. and Rees, W. (1996) Our ecological footprint: Reducing human impact on the Earth. New Society Publishers, Gabriola Island.

[23] Wackernagel, M., Onisto, L., Linares, A.C., Falfan, I.S.L., Garcia, J.M., Guerrero, I.S. and Guerrero, M.G.S. (1997) 
Ecological footprints of nations: How much nature do they use? How much nature do they have? Centre for Sustainability Studies, Universidad Anahuac de Xalapa, Mexico.

[24] Hoekstra, A.Y. and Chapagain, A.K. (2007) Water footprints of nations: Water use by people as a function of their consumption pattern. Water Resources Management, 21, 35-48. doi:10.1007/s11269-006-9039-x

[25] Yang, H., Wang, L. and Zehnder, A.J.B. (2007) Water scarcity and food trade in the southern and eastern Mediterranean countries. Food Policy, 32, 585-605. doi:10.1016/i.foodpol.2006.11.004

[26] Zimmer, D. and Renault, D. (2003) Virtual water in food production and global trade: Review of methodological issues and preliminary results. Proceedings of the International Expert Meeting on Virtual Water Trade, Delft, 93-107.

[27] Hoekstra, A.Y. and Hung, P.Q. (2005) Globalization of water resources. Global Environmental Change Part A, 15, 45-56. doi:10.1016/j.gloenvcha.2004.06.004

[28] Warner, J. (2003) Virtual water-virtual benefits. Proceedings of the International Expert Meeting on Virtual Water Trade, Delft, 125-135.

[29] Chapagain, A.K., Hoekstra, A.Y. and Savenije, H.H.G. (2006) Water saving through international trade of agricultural products, Hydrology and Earth System Sciences,
10, 455-468. doi:10.5194/hess-10-455-2006

[30] Lofgren, H. and Richards, A. (2003) Food security, poverty, and economic policy in the Middle East and North Africa. Trade and Macroeconomics Division, International Food Policy Research Institute, Washington.

[31] Hamouda, M. and El-Sadek, A. (2007) Virtual water trade as a policy option for the Arab States. Arab Water Council Journal, 1, 16-31.

[32] Abu-Zeid, M.A. (1998). Water and sustainable development: the vision for world water, life and the environment. Water Policy, 1, 9-19. doi:10.1016/S1366-7017(98)00002-6

[33] ESCWA (2004) The optimization of water resource management in the ESCWA countries: A survey of measures taken by the ESCWA countries during the 1990 s for the optimization of water resource management and capacity-building in the water sector. E/ESCWA/SDPD/2003/11.

[34] Hoekstra, A.Y. (1998) Appreciation of water: four perspectives. Water Policy, 1, 605-622. doi:10.1016/S1366-7017(99)00013-6

[35] El-Sadek, A. (2010) Water desalination: An imperative measure for water security in Egypt. Desalination, 250, 876-884. doi:10.1016/j.desal.2009.09.143 